\title{
HUBUNGAN PERUBAHAN DIVIDEN DENGAN PERUBAHAN LABA PERUSAHAAN TERDAFTAR DI BEI
}

\author{
Rendy Johan Gultom \\ Universitas Prasetiya Mulya \\ Edu Town Kavling Edu I No. 1, \\ Serpong, Jl. BSD Raya Utama, Pagedangan, Tangerang, Banten 15339
}

\begin{abstract}
This research aims to analyze the relation between dividend changes with earnings changes of the employee listed on Indonesia Stock Exchange (BEI) also to determine whether the dividend changes could predict the earnings changes. This study conducts two tests with two different research periods: during 2004 - 2006 and 2006 - 2008. The result of the research proves that dividend changes has a relationship with company's earnings changes in the future. From the test with two different research periods, shows that there is a negative correlation between dividend changes with earnings changes a year after dividend changes. This research also finds that dividend changes could predict earnings changes one year after dividend changes.
\end{abstract}

Keywords: dividend changes, earnings changes, Indonesia Stock Exchange (BEI)

\begin{abstract}
Abstrak
Penelitian ini bertujuan untuk menganalisis hubungan perubahan dividen dengan perubahan laba perusahaan yang terdaftar di Bursa Efek Indonesia serta menentukan apakah perubahan dividen mampu memprediksi perubahan laba. Studi ini menggunakan dua kali pengujian dengan dua periode penelitian yang berbeda yaitu: selama tahun 2004 - 2006 dan tahun $2006-2008$. Hasil penelitian ini membuktikan bahwa perubahan dividen memiliki hubungan dengan perubahan laba perusahaan di masa depan. Dari pengujian dengan periode penelitian yang berbeda, penelitian ini menemukan korelasi negatif antara perubahan dividen dengan perubahan laba yang terjadi satu tahun setelah perubahan dividen tersebut. Penelitian ini juga menemukan perubahan dividen mampu memprediksi perubahan laba dalam jangka waktu satu tahun setelah terjadinya perubahan dividen.
\end{abstract}

Kata kunci: perubahan dividen, perubahan laba, Bursa Efek Indonesia (BEI)

\section{PENDAHULUAN}

Kebijakan dividen yang ditentukan oleh suatu perusahaan berkaitan dengan kepentingan dua pihak yang berbeda, yakni pihak perusahaan dan pemegang saham. Bagi perusahaan, kebijakan 
dividen dapat memengaruhi kemampuan perusahaan dalam menyediakan dana yang dihasilkan secara internal. Bagi pemegang saham, dividen merupakan pendapatan yang diterima sebagai timbal balik atas penanaman modal yang dilakukan sebelumnya. Kebijakan dividen yang berbeda antara satu perusahaan dengan perusahaan lain mendorong banyaknya penelitian yang dilakukan menggunakan berbagai teori yang berbeda.

Penelitian awal tentang kebijakan dividen dilakukan oleh Litner (1956) dan menemukan bahwa investasi merupakan salah satu faktor yang menentukan besaran dividen yang dibagikan kepada pemegang saham. Penemuan tersebut didasarkan pada rendahnya rasio dividen terhadap laba pada masa-masa awal setelah perang dunia sebagai akibat dari investasi besar-besaran yang dilakukan perusahaan-perusahaan sampel setelah masa perang. Grullon, Michaely, dan Swaminathan (2002) juga menemukan korelasi kuat antara perubahan dividen dengan perubahan harga saham yang terjadi setelah perubahan dividen tersebut. Hasil penelitian Dasilas (2009) mendukung hasil penelitian Grullon, Michaely, dan Swaminathan (2002) yang menyatakan bahwa perubahan dividen memiliki hubungan erat dengan perubahan harga saham suatu perusahaan.

Selain penelitian mengenai hubungan antara perubahan dividen dengan perubahan saham terdapat juga penelitian yang menguji kemampuan dividen dalam mensinyalkan arus kas di masa depan. Brook, Charlton dan Hendershoot (2009) menemukan bahwa peningkatan pada arus kas perusahaan didahului oleh peningkatan pada dividen yang kepada pemegang saham sehingga dengan kata lain terdapat hubungan antara perubahan dividen dengan perubahan arus kas di masa depan. Fairchild (2008) juga menyatakan bahwa perubahan dividen merupakan sinyal atas rencana investasi perusahaan di masa depan, di mana peningkatan dividen mensinyalkan bahwa suatu 
perusahaan tidak melakukan investasi baru dan penurunan dividen mensinyalkan ketersediaan investasi positif bagi suatu perusahaan.

Penelitian terhadap kemampuan pensinyalan dividen tidak terbatas pada penelitian yang menguji hubungan perubahan dividen dengan perubahan harga saham dan arus kas semata. Dalam perkembangannya, penelitian mengenai kemampuan pensinyalan dividen turut diujikan pada hubungan perubahan dividen dengan perubahan laba yang terjadi setelah perusahaan melakukan perubahan dividen tersebut. Savov (2006) menemukan korelasi negatif antara perubahan dividen dengan perubahan laba yang terjadi satu tahun setelah perubahan dividen sebagai tindak lanjut dari ditemukannya korelasi kuat antara peningkatan dividen dengan penurunan laba yang terjadi satu tahun kemudian.

Penelitian ini bermaksud untuk mengetahui arah hubungan perubahan dividen dengan perubahan laba yang terjadi setelah perubahan dividen tersebut dan mengetahui kemampuan dividen dalam memprediksi perubahan laba yang terjadi setelah perusahaan melakukan perubahan dividen, karena penelitian yang sebelumnya tidak selalu menunjukkan adanya hubungan di antara keduanya. Peneliti menentukan pengambilan sampel terhadap perusahaan yang terdaftar di Bursa Efek Indonesia selama periode 2004 - 2008 dengan dua kali pengujian yakni, periode 2004 - 2006 (dengan ketentuan perusahaan tersebut membagi dividen dua tahun berturut-turut 2004 dan 2005) dan 2006 - 2008 (dengan ketentuan perusahaan tersebut membagi dividen dua tahun berturut-turut 2006 dan 2007). Peneliti mencari hubungan dari perubahan dividen selama periode $2004-2007$ dengan perubahan laba pada tahun 2008 . 
Demikian penelitian ini menjadi penelitian terkini tentang kebijakan dividen yang diterapkan pada perusahaan di Indonesia, dan menjadi bukti empiris atas hubungan perubahan dividen dengan perubahan laba serta berkontribusi pada penjelasan teori pensinyalan dividen (dividend signaling theory) terhadap laba perusahaan di masa depan. Selain itu penelitian ini dapat memberikan kontrubusi bagi pemegang saham dalam mengambil keputusan investasi lebih cepat, cermat dan akurat terkait dengan kebijakan dividen yang dimiliki oleh suatu perusahaan.

\section{LANDASAN TEORI DAN PENGEMBANGAN HIPOTESIS}

Laba yang dihasilkan perusahaan biasanya digunakan untuk dua tujuan, yakni: diinvestasikan kembali ke dalam bisnis dalam bentuk laba ditahan atau dibagikan kepada investor dalam bentuk dividen. Dividen menjadi suatu bentuk pendistribusian laba yang dilakukan oleh perusahaan kepada pihak investor berdasarkan proporsi kepemilikian oleh investor tersebut (Kimmel, Weygandt, \& Kiesso, 2015). Pembagian dividen tersebut biasanya diberikan dalam dua bentuk, yakni: bentuk kas dan saham. Pembagian dividen dalam bentuk kas dibagi lagi menjadi tiga, yakni: kas reguler, dividen extra, dan liquidating dividend. Pembayaran dividen extra dirasakan kurang efektif digunakan sebagai sinyal akan perubahan dalam prospek laba perusahaan, namun pembayaran dividen reguler menjadi cara yang paling efektif dalam melihat prospek laba suatu perusahaan.

Terkait dengan dividen ini perlu suatu perusahaan perlu menetapkan kebijakan untuk menentukan proporsi laba yang akan dibayarkan sebagai dividen kepada investor sebagai timbal balik atas dana yang ditanamkan dalam suatu perusahaan. Ada lima (5) kebijakan yang biasanya 
digunakan oleh perusahaan dalam membagikan laba dalam bentuk dividen, yakni: (1) kebijakan dividen stabil (besaran dividen yang dibagikan memiliki nilai tetap per lembar sahamnya sepanjang waktu tertentu walaupun laba perusahaan cenderung mengalami fluktuasi), (2) dividen meningkat (distribusi laba kepada investor dilakukan dalam jumlah yang meningkat dengan pertumbuhan yang stabil), (3) dividen dengan rasio konstan (besar dividen yang dibagikan mengikuti laba yang diperoleh perusahaan), (4) dividen reguler ditambah extra (laba didistribusikan kepada investor dengan menetapkan dividen per lembar saham kemudian ditambahkan dividen extra, yang ditentukan berdasarkan jumlah laba abnormal yang dihasilkan perusahaan pada tahun tersebut), (5) dividen residu (distribusi laba kepada investor dipengaruhi oleh investasi masa depan yang dimiliki perusahaan karena dividen yang dibagikan adalah sisa laba setelah digunakan untuk mendanai investasi).

Ada beberapa faktor internal di perusahaan yang memengaruhi penetapan atau penentuan suatu kebijakan dividen, yakni:

a) Rencana ekspansi: semakin besar ekspansi perusahaan memerlukan sumber dana internal yang besar pula sehingga perusahaan yang punya rencana ekspansi besar akan memiliki payout yang rendah karena laba digunakan untuk biaya rencana ekspansi

b) Investasi: perusahaan yang memiliki kesempatan melakukan investasi umumnya melakukan pembayaran dividen dalam jumlah kecil karena laba yang dihasilkan sebagian besar dimasukkan ke dalam laba ditahan untuk membiayai investasi di masa depan 
c) Hutang: perusahaan yang tidak menggunakan hutang sebagai sumber pendanaan utama akan membayarkan dividen dalam jumlah kecil karena laba digunakan sebagai sumber dana untuk modal perusahaan tersebut

d) Likuiditas: rendahnya tingkat likuiditas perusahaan umumnya berakibat pada pembayaran dividen dalam jumlah yang kecil atau rendah pula karena laba digunakan untuk menambah likuiditas perusahaan

e) Solvabilitas: perusahaan dengan solvabilitas rendah akan membayar dividen dalam jumlah rendah atau kecil pula karena laba digunakan untuk meningkatkan ekuitas perusahaan

Kebijakan dividen dalam suatu perusahaan dianggap sebagai suatu hal yang penting karena sering kali dikaitkan dengan harga saham perusahaan tersebut. Ada beberapa pandangan atau teori yang muncul terkait dengan hubungan dividen dengan harga saham, yaitu:

a) Dividen tidak relevan (Dividend Irrelevance Theory)

Teori yang dikembangkan awalnya oleh Miller \& Modigliani (1961) menyatakan bahwa tidak ada hubungan antara kebijakan dividen dengan harga saham suatu perusahaan. Lebih lanjut teori ini menegaskan bahwa pada pasar modal yang sifatnya sempurna tidak terdapat perbedaan ketika kebijakan payout suatu perusahaan dilakukan melalui pembayaran dividen ataupun melalui share repurchase.

b) Dividen yang tinggi meningkatkan nilai saham 


\section{saki}

Studi Akuntansi \& Keuangan Indonesia

Menurut pandangan ini pendapatan investor yang berasal dari pembagian dividen lebih berharga dibandingkan pendapatan yang berasal dari capital gain, maka perusahaan yang membayarkan dividen dalam jumlah besar dipandang mampu meningkatkan nilai saham

c) Dividen yang rendah meningkatkan nilai saham

Pandangan ini muncul karena ada perbedaan perlakukan pajak bagi pendapatan investor berupa capital gain atau dividen pada saat pembayaran pajak dan adanya pajak penghasilan. Pendapatan berupa dividen yang tinggi akan meningkatkan pajak penghasilan dan return setelah pajak akan menurun namun dividen yang rendah akan menunda timbulnya pajak penghasilan sehingga return setelah pajak akan maksimal atau tinggi.

Terdapat empat (4) teori yang muncul terkait dengan dividen, yakni:

\section{Teori Ekspektasi}

Teori ini mengemukakan bahwa dampak yang dihasilkan dari suatu informasi mengenai suatu perusahaan terhadap harga saham perusahaan tersebut bergantung pada bagaimana informasi bila dibandingkan dengan ekspektasi yang terbentuk sebelumnya. Pada saat informasi aktual sama dengan ekspektasi yang terbentuk, maka harga saham suatu perusahaan tidak mengalami perubahan meskipun misalnya terjadi peningkatan pembayaran dividen dari tahun sebelumnya. Namun apabila terjadi sebaliknya, maka investor akan melakukan penilaian kembali terhadap perusahaan tersebut.

\section{The Clientele Effect}

Menurut teori ini, kebijakan dividen dalam suatu perusahaan merupakan preferensi optimal dari investor dari beban pajak sehingga investor cenderung memilih perusahaan yang memiliki kebijakan dividen yang sesuai dengan beban pajak yang ditanggung investor tersebut. Mori (2009) 
dalam penelitiannya menegaskan bahwa investor individu cenderung memilih saham yang tidak atau sedikit membayarkan dividen sedangkan investor korporasi lebih cenderung memilih saham yang membayarkan dividen yang tinggi walaupun ada sebagian investor korporasi yang tidak melakukan hal yang sama.Tingkat dividen optimal bagi investor korporasi berkaitan erat dengan kebutuhan akan arus kas (dengan menggunakan asumsi bahwa tingkat pajak akan selalu konstan sepanjang waktu).

\section{Teori Biaya Keagenan (Agency Cost Theory)}

Hubungan keagenan dalam suatu perusahaan cenderung memunculkan adanya konflik kepentingan antara pihak prinsipal (investor) dengan pihak agen (manajemen perusahaan). Investor selaku pihak prinsipal dapat mengurangi konflik ini melalui pemberian insentif kepada pihak manajemen dan juga bersedia melakukan pengawasan untuk mencegah terjadinya penyimpangan oleh pihak manajemen. Biaya yang dikeluarkan investor untuk memberikan insentif serta pengawasan ini merupakan biaya keagenan (agency cost).

\section{The Signaling Theory}

Berdasarkan teori ini, dividen dapat digunakan sebagai alat untuk menyampaikan sinyal atas prospek perusahaan di masa yang akan datang. Hal ini dapat terjadi karena terdapat asymmetric information antara pihak manajemen perusahaan dan investor. Dengan kata lain, manajemen perusahaan umumnya lebih mengetahui dan kondisi perusahaan dibandingkan investor, sehingga kebijakan dividen digunakan untuk mengurangi perbedaan informasi antara manajemen dan investor tersebut. Kebijakan dividen dapat digunakan untuk menyampaikan prospek perusahaan di 
masa yang akan datang kepada investor berupa gambaran mengenai harga saham, arus kas, atau laba yang dihasilkan di masa yang akan datang.

Grullon, Michaely, dan Swaminathan (2002) menemukan bahwa perubahan dividen yang dilakukan perusahaan memiliki hubungan dengan perubahan harga saham yang terjadi setelah perubahan dividen tersebut. Sementara itu, Joos dan Plesko (2004) mencoba menguji hubungan antara perubahan dividen dengan perubahan arus kas perusahaan yang terbentuk setelah perubahan dividen. Penelitian tersebut menemukan korelasi yang tinggi antara perubahan dividen meningkat dengan penurunan laba yang terjadi setelah perubahan dividen. Perubahan dividen meningkat memiliki kemampuan prediksi yang lebih tinggi pada perusahaan yang mengalami penurunan laba dengan arus kas negatif dibandingkan pada perusahaan yang mengalami penurunan laba dengan arus kas positif.

Savov (2006) juga mencoba menguji hubungan perubahan dividen dengan perubahan performa operasional perusahaan setelah tejadinya perubahan dividen. Hasil penelitian ini ternyata tidak dapat menemukan hubungan antara perubahan dividen meningkat dengan perubahan laba meningkat yang terjadi setelah perubahan dividen tersebut sebaliknya menemukan bahwa laba perusahaan-perusahaan yang dijadikan sampel justru mengalami penurunan setelah terjadinya peningkatan dividen. Dengan kata lain, kemampuan dividen sebagai sinyal justru ditemukan pada peningkatan dividen dengan penurunan laba yang terjadi setelah peningkatan dividen tersebut. Verdugo (2006) dalam penelitiannya di perusahaan-perusahaan dengan serikat buruh di Amerika menemukan bahwa peran dividen sebagai sinyal akan melemah. Hal ini diakibatkan karena serikat buruh turut memengaruhi perusahaan dalam menentukan kebijakan dividen. Perusahaan dengan 
serikat buruh yang lemah ditemukan hubungan atau korelasi negatif yang kuat antara perubahan dividen dengan perubahan laba yang terjadi kemudian. Sementara itu, perusahaan dengan serikat buruh yang kuat, korelasi antara perubahan dividen dengan perubahan laba yang terjadi setelah perubahan dividen sangat lemah.

Dari beberapa penelitian di atas pada dasarnya ditemukan bahwa dividen dapat digunakan sebagai sinyal atas kondisi harga saham perusahaan, arus kas, dan laba perusahaan di masa depan. Hasil penelitian yang berbeda pada penelitian-penelitian terdahulu tentang kemampuan dividen dalam mensinyalkan laba masa depan mendorong peneliti untuk menguji hubungan dividen dengan laba masa depan. Ada beberapa faktor yang memengaruhi kebijakan dividen suatu perusahaan seperti misalnya ekspansi dan investasi. Perusahaan yang memiliki rencana ekspansi akan menggunakan laba sebagai sumber dana untuk investasi tersebut sehingga pendistribusian laba tidak dimaksimalkan. Penelitian ini mencoba untuk menggunakan asumsi atau dugaan bahwa terdapat hubungan negatif antara perubahan dividen dengan perubahan laba yang terjadi setelah perubahan dividen tersebut. Ada dua (2) hipotesa yang hendak dibuktikan atau diuji dalam penelitian ini, yaitu:

1. Perubahan dividen memiliki korelasi negatif dengan perubahan laba satu tahun kemudian

2. Perubahan dividen memiliki kemampuan prediksi atas perubahan laba satu tahun kemudian

\section{METODE PENELITIAN}

Metode yang digunakan dalam penelitian ini digunakan untuk menentukan ada tidaknya hubungan perubahan dividen dengan perubahan laba yang terjadi setahun setelah perubahan dividen tersebut. Penelitian ini menggunakan dua (2) kali pengujian dengan rentang waktu yang berbeda. 
Pertama, penelitian ini menguji hubungan antara perubahan dividen yang terjadi pada tahun 2005 dengan perubahan laba pada tahun 2006. Kedua, pengujian yang sama dilakukan dengan menggunakan perubahan dividen yang terjadi pada tahun 2007 dan perubahan laba pada tahun 2008. Adapun data yang digunakan dalam penelitian ini adalah data sekunder yang didapatkan dari buku JSX Statistics tahunan. Pengujian pertama menggunakan data dari JSX Statistics tahun 2004 2006. Pengujian kedua menggunakan data dari JSX Statistics tahun 2006 - 2008.

Pada tahun 2005 terdapat 334 perusahaan yang terdaftar di Bursa Efek Indonesia dan sebanyak 230 perusahaan tidak membagikan dividen. Pengujian pertama menggunakan dua (2) kriteria dalam penentuan pengambilan sampel, yaitu: (a) perusahaan dengan dividen tidak berubah tidak disertakan dalam sampel penelitian, (b) perusahaan dengan perubahan dividen yang sangat besar juga tidak disertakan dalam sampel penelitian. Dari kriteria penentuan sampel tersebut diperoleh sampel pada pengujian pertama sebanyak 32 perusahaan dengan rincian sebagai berikut:

1. Sebanyak 22 perusahaan yang mengalami perubahan dividen meningkat tahun 2005 dan laba menurun di tahun 2006

2. Sebanyak 10 perusahaan yang mengalami perubahan dividen menurun tahun 2005 dan laba meningkat di tahun 2006

Pada tahun 2007 terdapat 391 perusahaan yang terdaftar di Bursa Efek Indonesia dan sebanyak 293 perusahaan tidak membagikan dividen. Pengujian kedua juga menggunakan kriteria yang sama dalam penentuan pengambilan sampel dan diperoleh sampel sebanyak 30 perusahaan dengan rincian sebagai berikut: 
1. Sebanyak 11 perusahaan yang mengalami perubahan dividen meningkat tahun 2007 dan laba menurun di tahun 2008

2. Sebanyak 19 perusahaan yang mengalami perubahan dividen menurun tahun 2007 dan laba meningkat di tahun 2008

Variabel dependen yang digunakan adalah perubahan laba yang didapatkan dari perubahan yang terjadi antara laba usaha pada satu tahun dengan laba usaha pada tahun sebelumnya. Variabel laba usaha digunakan dalam penelitian ini karena penelitian ini ingin mengetahui pengaruh perubahan dividen terhadap perubahan laba yang terjadi setahun setelah perubahan dividen tersebut. Sementara itu, variabel independen yang digunakan adalah perubahan dividen yang diperoleh dari perubahan dividen per lembar saham pada satu tahun terhadap dividen per lembar saham pada tahun sebelumnya.

Ada dua (2) model yang digunakan dalam penelitian ini, yaitu:

1. Model korelasi: digunakan untuk menemukan korelasi negatif antara perubahan dividen dengan perubahan laba satu tahun kemudian.

$$
r=\frac{n \Sigma X Y-(\Sigma X)(\Sigma Y)}{\sqrt{\left.g n \Sigma X^{2}-(\Sigma X)^{2}\right\}\left\{n \Sigma Y^{2}-(\Sigma Y)^{2}\right)}}
$$

\section{Keterangan model:}

$\mathrm{n} \quad=$ jumlah sampel penelitian

$\mathrm{X}=$ perubahan dividen (1)

$\mathrm{Y} \quad=$ perubahan laba satu tahun setelah perubahan dividen 
Dalam penelitian ini, korelasi negatif tersebut dapat diinterpretasikan bahwa peningkatan yang terjadi pada dividen memiliki korelasi pada penurunan laba yang terjadi satu tahun kemudian dan penurunan dividen memiliki korelasi dengan peningkatan laba yang terjadi satu tahun kemudian.

2. Model regresi: digunakan untuk menemukan kemampuan prediksi perubahan dividen atas perubahan laba satu tahun setelah perubahan dividen tersebut.

$$
\left(E_{t+1}-E_{t}\right) / E_{t}=\alpha_{0}+\alpha_{1}\left(\operatorname{Div}_{t}-\operatorname{Div}_{t-1}\right) / \operatorname{Div}_{t-1}+\varepsilon_{t}
$$

Keterangan model:

$\mathrm{E}_{\mathrm{t}+1} \quad=$ laba usaha pada tahun $\mathrm{t}+1$

$\mathrm{E}_{\mathrm{t}} \quad=$ laba usaha pada tahun $\mathrm{t}$

Div $\mathrm{t}=$ dividen per lembar saham pada tahun $\mathrm{t}$

$\operatorname{Div}_{\mathrm{t}-1}=$ dividen per lembar saham pada tahun $\mathrm{t}-1$

Pada dua pengujian yang berbeda di penelitian ini digunakan juga dua model regresi, yaitu:

a. Model regresi pengujian pertama untuk menemukan kemampuan prediksi perubahan dividen tahun 2005 atas perubahan laba pada tahun 2006

$$
\left(E_{2006}-E_{2005}\right) / E_{2005}=\alpha_{0}+\alpha_{1}\left(\operatorname{Div}_{2005}-\operatorname{Div}_{2004}\right) / \operatorname{Div}_{2004}+\varepsilon_{t}
$$

Keterangan model:

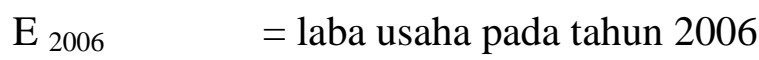

$\mathrm{E}_{2005}=$ laba usaha pada tahun 2005

Div $_{2005}=$ dividen per lembar saham tahun 2005

Div $2004=$ dividen per lembar saham tahun 2004 
b. Model regresi pengujian kedua untuk menemukan kemampuan prediksi perubahan dividen tahun 2007 atas perubahan laba tahun 2008

$$
\left(E_{2008}-E_{2007}\right) / E_{2007}=\alpha_{0}+\alpha_{1}\left(\operatorname{Div}_{2007}-\operatorname{Div}_{2006}\right) / \operatorname{Div}_{2006}+\varepsilon_{\mathrm{t}}
$$

Keterangan model:

$\mathrm{E}_{2008} \quad=$ laba usaha pada tahun 2008

$\mathrm{E}_{2007}=$ laba usaha pada tahun 2007

$\operatorname{Div}_{2007}=$ dividen per lembar saham tahun 2007

Div 2006 = dividen per lembar saham tahun 2006

\section{PEMBAHASAN (ANALISIS \& HASIL)}

Metode penelitian yang sudah ditentukan digunakan untuk menguji dua hipotesa, yaitu:

1. Apakah terdapat korelasi negatif antara perubahan dividen dengan perubahan laba yang terjadi satu tahun setelah perubahan dividen tersebut

Dalam pengujian pertama atas hipotesis pertama tersebut dengan mengacu pada perubahan dividen tahun 2005 terhadap perubahan laba tahun 2006 diperoleh angka korelasi sebesar -0.589.

Tabel 1.

Korelasi Perubahan Dividen 2005 dengan Perubahan Laba 2006 


\begin{tabular}{|c|c|c|c|}
\hline & & Perubahan Laba 2006 & $\begin{array}{c}\text { Perubahan Dividen } \\
2005 \\
\end{array}$ \\
\hline \multirow[t]{2}{*}{ Pearson Correlation } & $\begin{array}{l}\text { Perubahan Laba } \\
2006\end{array}$ & 1.000 & -.589 \\
\hline & $\begin{array}{l}\text { Perubahan } \\
\text { Dividen } 2005\end{array}$ & -.589 & 1.000 \\
\hline \multirow[t]{2}{*}{ Sig. (1-tailed) } & $\begin{array}{l}\text { Perubahan Laba } \\
2006\end{array}$ & . & .000 \\
\hline & $\begin{array}{l}\text { Perubahan } \\
\text { Dividen } 2005\end{array}$ & .000 & . \\
\hline \multirow[t]{2}{*}{$\mathrm{N}$} & $\begin{array}{l}\text { Perubahan Laba } \\
2006\end{array}$ & 32 & 32 \\
\hline & $\begin{array}{l}\text { Perubahan } \\
\text { Dividen } 2005\end{array}$ & 32 & 32 \\
\hline
\end{tabular}

Angka korelasi sebesar -0.589 yang ditunjukkan dalam tabel 1 di atas setelah data diolah dengan SPSS ditafsirkan menurut kriteria sebagai berikut:

$0-0.25 \quad$ : korelasi sangat lemah (dianggap tidak ada)

$>0.25-0.5 \quad$ : korelasi cukup

$>0.5-0.75$ : korelasi kuat

$>0.75-1 \quad$ : korelasi sangat kuat

Sumber: Analisa Jalur untuk Riset Bisnis dengan SPSS (Sarwono, 2007)

Mengacu pada kriteria di atas, korelasi sebesar -0.589 menjelaskan bahwa terdapat korelasi kuat antara perubahan dividen tahun 2005 dengan perubahan laba tahun 2006. Tanda negatif pada angka korelasi menunjukkan bahwa perubahan dividen meningkat tahun 2005 memiliki hubungan dengan laba menurun tahun 2006 (begitu pula sebaliknya). 
Sementara itu dalam pengujian kedua atas hipotesa pertama di atas dengan mengacu pada perubahan dividen tahun 2007 dengan perubahan laba tahun 2008 diperoleh angka korelasi sebesar -0.505 .

Tabel 2.

Korelasi Perubahan Dividen 2007 dengan Perubahan Laba 2008

\begin{tabular}{|cc|c|c|}
\hline & & $\begin{array}{c}\text { Perubahan } \\
\text { Laba 2008 }\end{array}$ & $\begin{array}{c}\text { Perubahan Dividen } \\
2007\end{array}$ \\
\hline Pearson Correlation & Perubahan Laba 2008 & 1.000 & -.505 \\
& Perubahan Dividen 2007 & -.505 & 1.000 \\
\hline \multirow{2}{*}{ Sig. (1-tailed) } & Perubahan Laba 2008 &. & .002 \\
& Perubahan Dividen 2007 & .002 &. \\
\hline \multirow{2}{*}{$\mathrm{N}$} & Perubahan Laba 2008 & 30 & 30 \\
& Perubahan Dividen 2007 & 30 & 30 \\
\hline
\end{tabular}

Dari tabel di atas angka korelasi -0.505 menunjukkan korelasi kuat antara perubahan dividen tahun 2007 dengan perubahan laba tahun 2008. Tanda negatif pada angka korelasi menunjukkan bahwa perubahan dividen meningkat tahun 2007 memiliki hubungan dengan laba menurun tahun 2008 (begitu pula sebaliknya).

2. Apakah perubahan dividen mampu memprediksi perubahan laba yang terjadi satu tahun setelah perubahan dividen tersebut.

Dalam pengujian pertama atas hipotesa kedua tersebut dengan mengacu pada perubahan dividen tahun 2005 dan perubahan laba tahun 2006 diperoleh angka $p$-value sebesar 0.000.

Tabel 3.

Regresi Perubahan Dividen 2005 dengan Perubahan Laba 2006 


\begin{tabular}{|c|c|c|c|c|c|c|}
\hline & \multirow[b]{2}{*}{ Model } & \multicolumn{2}{|c|}{$\begin{array}{c}\text { Unstandardized } \\
\text { Coefficients }\end{array}$} & \multirow{2}{*}{$\begin{array}{c}\begin{array}{c}\text { Standardized } \\
\text { Coefficients }\end{array} \\
\text { Beta }\end{array}$} & \multirow[b]{2}{*}{$\mathrm{T}$} & \multirow[b]{2}{*}{ Sig. } \\
\hline & & B & Std. Error & & & \\
\hline \multirow[t]{2}{*}{1} & (Constant) & -.083 & .051 & & -1.620 & .116 \\
\hline & $\begin{array}{c}\text { Perubahan } \\
\text { Dividen } 2005\end{array}$ & -.125 & .031 & -.589 & -3.990 & .000 \\
\hline
\end{tabular}

Nilai $p$-value sebesar 0.000 sesuai tabel di atas lebih rendah dibandingkan angka taraf nyata (0.05) sehingga dapat diinterpretasikan bahwa perubahan dividen tahun 2005 memiliki kemampuan prediksi atas perubahan laba tahun 2006.

Sementara itu dalam pengujian kedua di atas dengan mengacu pada perubahan dividen tahun 2007 dengan perubahan laba tahun 2008 diperoleh angka p-value sebesar 0.004 .

Tabel 4.

Regresi Perubahan Dividen 2007 dengan Perubahan Laba 2008

\begin{tabular}{|c|c|c|c|c|c|c|}
\hline \multirow{2}{*}{\multicolumn{2}{|c|}{ Model }} & \multicolumn{2}{|c|}{$\begin{array}{l}\text { Unstandardized } \\
\text { Coefficients }\end{array}$} & \multirow{2}{*}{\begin{tabular}{|c}
$\begin{array}{c}\text { Standardized } \\
\text { Coefficients }\end{array}$ \\
Beta
\end{tabular}} & \multirow[b]{2}{*}{$\mathrm{t}$} & \multirow[b]{2}{*}{ Sig. } \\
\hline & & B & Std. Error & & & \\
\hline \multirow[t]{3}{*}{1} & (Constant) & .275 & .089 & & 3.089 & .005 \\
\hline & Perubahan & & & & בר & \\
\hline & Dividen 2007 & .102 & כנכט. & דo. & 3.072 & .004 \\
\hline
\end{tabular}

Nilai p-value sebesar 0.004 sesuai tabel di atas lebih rendah dibandingkan angka taraf nyata (0.05) sehingga dapat diinterpretasikan bahwa perubahan dividen tahun 2007 memiliki kemampuan prediksi atas perubahan laba tahun 2008 .

Hasil penelitian ini mendukung penelitian Nissim dan Ziv (2001) juga Lukose dan Rao (2004) yang menemukan korelasi antara perubahan dividen dengan perubahan laba yang terjadi perubahan dividen tersebut. Selain itu, penelitian ini juga mendukung penelitian Joos dan Plesko 
(2004) serta Savov (2006) yang menemukan korelasi negatif yang kuat antara perubahan dividen dengan perubahan laba yang terjadi kemudian.

Penelitian ini juga mendukung signaling theory pada dividen karena perubahan dividen perusahaan yang dijadikan sampel dalam penelitian ini memiliki hubungan dengan perubahan laba yang terjadi satu tahun setelah perubahan dividen tersebut. Dengan adanya investasi, kemampuan perusahaan dalam membagikan dividen menjadi berkurang, namun pengurangan dividen ini dikompensasikan dengan peningkatan laba di masa depan akibat adanya kegiatan investasi yang telah dilakukan. Dengan demikian, penurunan dividen mensinyalkan ketersediaan peluang investasi bagi perusahaan yang dapat meningkatkan laba di masa depan. Selain berkaitan dengan pendanaan investasi, hubungan negatif antara perubahan dividen dengan perubahan laba masa depan turut dapat dijelaskan dengan tindakan manajemen terhadap hutang yang dimiliki oleh suatu perusahaan.

Peneliti mengembangkan model penelitian utama yang digunakan pada penelitian ini. Pada model utama, variabel penelitian terdiri atas perubahan dividen, sedangkan model pada robustness check menggunakan beberapa variabel independen seperti: perubahan dividen, ukuran perusahaan, perubahan investasi, perubahan hutan dan ROE (return on equity). Di bawah ini adalah model yang digunakan pada robustness check.

$$
\begin{aligned}
\left(\mathrm{E}_{\mathrm{t}+1}-\mathrm{E}_{\mathrm{t}}\right) / \mathrm{E}_{\mathrm{t}}= & \alpha_{0}+\alpha_{1} *\left(\text { Div }_{\mathrm{t}}-\operatorname{Div}_{\mathrm{t}-1}\right) / \text { Div }_{\mathrm{t}-1}+\alpha_{2} * \operatorname{Ln}\left(\text { Assets }_{\mathrm{t}}\right) \\
& +\alpha_{3} *\left(\text { Assets }_{\mathrm{t}}-\text { Assets }_{\mathrm{t}-1}\right) / \text { Assets }_{\mathrm{t}-1} \\
& +\alpha_{4}^{*}\left(\text { LT.Liabilities }_{\mathrm{t}}-\text { LT.Liabilities }_{\mathrm{t}-1}\right) / \text { LT.Liabilities }_{\mathrm{t}-1}+\alpha_{5} * \text { ROE }_{\mathrm{t}}
\end{aligned}
$$

Keterangan model: 
$\mathrm{E}_{\mathrm{t}+1}$

$\mathrm{E}_{\mathrm{t}}$

$\operatorname{Div}_{\mathrm{t}}$

$\operatorname{Div}_{\mathrm{t}-1}$

Assets $_{\mathrm{t}}$

Assets $_{\text {t-1 }}$

LT.Liabilities

LT.Liabilities $_{\mathrm{t}-1}$

$\mathrm{ROE}_{\mathrm{t}}$
= laba usaha pada tahun $t+1$

= laba usaha pada tahun $\mathrm{t}$

$=$ dividen per lembar saham pada tahun $\mathrm{t}$

$=$ dividen per lembar saham pada tahun $\mathrm{t}-1$

$=$ total aktiva pada tahun $\mathrm{t}$

$=$ total aktiva pada tahun $\mathrm{t}-1$

$=$ total kewajiban jangka panjang pada tahun $\mathrm{t}$

$=$ total kewajiban jangka panjang pada tahun $\mathrm{t}-1$

= return on equity pada tahun $\mathrm{t}$

Hasil pengolahan data pada robustness check diperoleh hasil seperti tabel di bawah ini:

Tabel 5.

Model Summary pada Robustness Check

\begin{tabular}{|c|c|c|c|c|c|}
\hline Model & $\mathrm{R}$ & $\mathrm{R}$ Square & $\begin{array}{c}\text { Adjusted } \mathrm{R} \\
\text { Square }\end{array}$ & $\begin{array}{c}\text { Std. Error of } \\
\text { the Estimate }\end{array}$ & $\begin{array}{c}\text { Durbin- } \\
\text { Watson }\end{array}$ \\
\hline 1 & $.133^{\mathrm{a}}$ & .018 & -.002 & 2.9873112 & 1.992 \\
\hline
\end{tabular}

a. Predictors: (Constant), ROE, Dividend Change, Assets Change, Size, Debt change

b. Dependent Variable: Earning Change

Nilai $R$ square $\left(\mathrm{r}^{2}\right)$ sesuai tabel di atas adalah 0,018 yang diinterpretasikan bahwa variabilitas perubahan laba yang dapat dijelaskan dengan menggunakan variabel perubahan dividen, ukuran perusahaan, perubahan investasi, perubahan hutang, serta ROE sebesar $1.80 \%$ sedangkan sebanyak 98.20\% dijelaskan oleh variabel lain di luar model untuk robustness check ini.

Tabel 6.

Coefficients pada Robustness Check 


\begin{tabular}{|c|c|c|c|c|c|c|c|c|c|c|}
\hline \multirow[b]{2}{*}{ Mod } & & \multicolumn{2}{|c|}{$\begin{array}{l}\text { Unstandardized } \\
\text { Coefficients }\end{array}$} & \multirow{2}{*}{\begin{tabular}{c|}
$\begin{array}{c}\text { Standardized } \\
\text { Coefficients }\end{array}$ \\
Beta \\
\end{tabular}} & \multirow[b]{2}{*}{$\mathrm{t}$} & \multirow[b]{2}{*}{ Sig. } & \multicolumn{2}{|c|}{$\begin{array}{c}95 \% \text { Confidence } \\
\text { Interval for B }\end{array}$} & \multicolumn{2}{|c|}{$\begin{array}{l}\text { Collinearity } \\
\text { Statistics }\end{array}$} \\
\hline & & B & $\begin{array}{l}\text { Std. } \\
\text { Error }\end{array}$ & & & & $\begin{array}{l}\text { Lower } \\
\text { Bound }\end{array}$ & $\begin{array}{l}\text { Upper } \\
\text { Bound }\end{array}$ & Tolerance & VIF \\
\hline \multirow[t]{6}{*}{1} & (Constant) & 2.368 & 1.422 & & 1.665 & .097 & -.433 & 5.169 & & \\
\hline & $\begin{array}{l}\text { Dividend } \\
\text { Changes }\end{array}$ & .000 & .006 & -.004 & -.058 & .954 & -.012 & .012 & .988 & 1.012 \\
\hline & Size & -.095 & .100 & -.063 & $|-.948|$ & .344 & -.293 & .103 & .890 & 1.123 \\
\hline & $\begin{array}{l}\text { Assets } \\
\text { Changes }\end{array}$ & -.435 & .681 & -.046 & $\mid-639$ & .523 & -1.777 & .906 & .756 & 1.323 \\
\hline & $\begin{array}{l}\text { Debt } \\
\text { Changes }\end{array}$ & .016 & .021 & .056 & .771 & .441 & -.025 & .056 & .750 & 1.333 \\
\hline & ROE & -1.727 & 1.363 & -.087 & $\left|\begin{array}{c}- \\
1.267\end{array}\right|$ & .206 & -4.412 & .958 & .833 & 1.200 \\
\hline
\end{tabular}

a. Dependent variable: earnings change

Dari tabel coefficients di atas angka signifikansi untuk variabel perubahan dividen (0.954), variabel ukuran perusahaan (0.344), variabel perubahan investasi (0.523), variabel perubahan hutang $(0.441)$ dan variabel ROE (0.206) menunjukkan angka lebih besar dari alpha (0.05). Kondisi ini menyatakan bahwa variabel-variabel tersebut tidak memiliki kemampuan prediksi atas perubahan laba yang terjadi di masa depan. Hasil robustness check dengan memasukkan beberapa variabel tambahan ternyata menemukan hasil yang berbeda dengan hasil penelitian dengan menggunakan model utama, karena tidak menemukan kemampuan prediksi perubahan dividen terhadap perubahan laba satu tahun kemudian.

\section{KESIMPULAN}

Penelitian ini menegaskan bahwa terdapat hubungan antara perubahan dividen dengan perubahan laba yang terjadi satu tahun setelah perubahan dividen tersebut. Hubungan ini ditemukan 
baik pada pengujian pertama dan kedua dalam penelitian ini dengan dua periode penelitian yang berbeda 2004 - 2006 dan 2006 - 2008. Penelitian ini juga turut menemukan kemampuan dividen dalam memprediksi laba masa depan suatu perusahaan. Hasil regresi pada pengujian satu (periode 2004 - 2006) dan pengujian kedua (periode 2006 - 2008) menemukan kemampuan perubahan dividen meningkat dalam memprediksi perubahan laba menurun serta perubahan dividen menurun dalam memprediksi perubahan laba meningkat yang terjadi satu tahun setelah perubahan dividen tersebut. Ketersediaan peluang investasi bagi perusahaan merupakan salah satu penjelasan yang dapat menjelaskan hubungan antara perubahan dividen dengan perubahan laba yang ditemukan dalam penelitian ini.

Peneliti dalam penelitian ini menemukan beberapa keterbatasan, yakni: sampel penelitian hanya menggunakan perusahaan yang terdaftar di Bursa Efek Indonesia, penelitian tidak menguji hubungan serta kemampuan prediksi perubahan dividen pada jangka waktu lebih dari satu tahun setelah terjadinya perubahan dividen tersebut, dan penelitian ini mengukur perubahan dividen dalam bentuk kas dan tidak mengikutsertakan dividen dalam bentuk saham. Dari kondisi ini, peneliti menyarankan untuk melakukan penelitian serupa di kemudian hari dengan lebih mempertimbangkan keterbasatan tersebut dan termasuk turut menguji pula hubungan antara perubahan dividen dengan perubahan arus kas dari kegiatan investasi serta hubungan antara perubahan arus kas dari kegiatan investasi dengan perubahan laba di masa depan. 


\section{SENARAI PUSTAKA}

Brook, Y., Charlton, W.T., \& Hendershott, R.J. (2009). Do Firm Use Dividends to Signal Large Future Cash Flow Increasess? Financial Management, 27 (3), 46 - 57.

Dasilas, A. (2009). Stock Market Reaction to Dividend Announcements: Evidence from Greek Stock Market. Working Paper of Macedonia University

Fairchild, R.J. (2008). Dividend Policy, Signaling and Free Cashflow: An Integrated Approach. Journal of Finance.

Grullon, G., R. Michaely, \& B. Swaminathan. (2002). Are Dividend Changes a Sign of Firm Maturity? Journal of Business, 75, 387 - 424.

Joos, P., \& George, A.P. (2004). Costly Dividend Signaling. Working Paper of MIT Sloan School of Management.

Kimmel, P.D., Jerry, J.W., \& Donald, E.K. (2015). Financial Accounting $8^{\text {th }} e d$. John Wiley \& Sons, Inc.

Lukose, J., \& Narayan, R. (2004). Dividend Changes, Profitability and Earnings. Working Paper of Institute Financial Management and Research Institute.

Mori, Naoya. (2009). Tax Clientele Effects of Dividends Under Intertemporal Consumption Choices. Working Paper of Nihon University, Japan.

Nissim, D., \& Amir, Z. (2001). Dividend Changes and Future Profitability. The Journal of Finance, Vol. LVI (6).

Savov, S. (2006). Dividend Changes, Signaling and Stock Price. Mannheim Finance Working Paper, (3)

Verdugo, A.R. (2006). Dividend Signaling and Unions. Working Paper of Massachussets Institute of Technology. 